\title{
Agroecological Transition from Farms to Territorialised Agri-Food Systems: Issues and Drivers
}

\author{
Marie-Benoît Magrini, Guillaume Martin, Marie-Angélina Magne, \\ Michel Duru, Nathalie Couix, Laurent Hazard, and Gaël Plumecocq
}

\begin{abstract}
Agroecological transition corresponds to a systemic transformation consisting in the ecologisation of agriculture and food. It concerns multiple stakeholders (farmers, supply chains, natural resource managers, etc.) and is characterised by a deliberate political intention to bring about change. This chapter highlights a set of determinants of agroecological transition at play in transforming the techniques and the values underpinning both agricultural production and food consumption choices - both of which can lead to various new agri-food systems. Based on the literature on transition studies, we focus on several considerations that could help stakeholders to better engage in such a process: (i) transition takes place over time intervals that vary, depending on the analysis scale (the farm or the agri-food system as a whole); (ii) transition is complex, systemic and requires changes of the whole sociotechnical regime; (iii) transition implies strong connections between nicheinnovations and the dominant sociotechnical regime; and (iv) changes in values and individuals' abilities are fundamental drivers. Hence, by focusing on the plurality of factors and stakeholders at work, we unpack the complexity of this transition, and in this way help the stakeholders to design and execute it. To conclude, we examine specific issues around the governance of agroecological transition.
\end{abstract}

M.-B. Magrini $(\varangle) \cdot$ G. Martin $\cdot$ M. Duru $\cdot$ N. Couix $\cdot$ L. Hazard AGIR, Université de Toulouse, INRA, Castanet-Tolosan, France e-mail: marie-benoit.magrini@inra.fr; guillaume.martin@inra.fr; michel.duru@inra.fr; nathalie.couix@inra.fr; laurent.hazard@inra.fr

M.-A. Magne

AGIR, Université de Toulouse, INRA, ENSFEA, Castanet-Tolosan, France

e-mail: marie-angelina.magne@inra.fr

G. Plumecocq

AGIR, Université de Toulouse, INRA, Castanet-Tolosan, France

LEREPS, Université de Toulouse, ENSFEA, Toulouse, France

e-mail: gael.plumecocq@inra.fr 


\section{Introduction: What Agroecological Transition Are We Talking About?}

Faced with the urgency of sustainable development and the crises that the agricultural sector is experiencing, successive governments in France have strengthened measures to make agriculture more ecological. Since the "Ecophyto 2018" plan adopted by the Ministry of Agriculture in 2008, and up until the new agricultural framework law (the Loi d'avenir of 13 October 2014) that makes explicit reference to agroecology, institutional measures have been strengthened to encourage farmers to adopt more sustainable practices. Farmers are urged to implement alternative production strategies to reduce synthetic input use and to combine economic, environmental, and social performance. This political injunction to adopt agroecology is situated beyond the reference framework of organic agriculture, which today remains the only alternative framework officially recognised by governmentapproved labelling.

This agricultural transformation also calls food into question (Francis et al. 2003; Barbier and Elzen 2012; Hinrichs 2014; Gliessman 2015). The FAO (2012: 8) defines the sustainability of our food as being closely related to that of our agriculture, according to the following five criteria ${ }^{1}$ : (i) protects ecosystem biodiversity; (ii) is accessible and culturally acceptable; (iii) is economically fair and affordable; (iv) is safe, nutritionally adequate, and healthy; and v) optimises natural and human resource use. The sustainability of agriculture and food systems thus simultaneously involves technical changes and the values that govern them: it requires the implementation of "non-technological changes such as those in consumer behaviour, social norms, cultural values, and formal institutional frameworks" (OECD 2010: 32). This is even more relevant, given that our "agricultural practices are not primarily determined by agronomic or ecological science, but by markets, regulations and agricultural support programs" (Weiner 2017: 869).

This systemic transformation consisting in ecologising our agriculture and food, which concerns multiple stakeholders (farmers, supply chains, or natural resource managers) and which is marked with a deliberate political will to change, is qualified as an agroecological transition (Duru et al. 2015a). Note that it is a transition and not a revolution, because it does not explicitly entail the need for other changes relative to the capitalist foundations of the societal model underpinning our agriculture and food (cf. Hinrichs 2014 or Brown et al. 2012 on this point). ${ }^{2}$ It is a transition

\footnotetext{
${ }^{1}$ The FAO adopted this definition during the International Scientific Symposium on Biodiversity and Sustainable Diets in 2010.

2 "processes of transition may contain weighty seeds of ambition; but typically do not anticipate a wholesale shift in the future economic mode of production" (Brown et al. 2012). Research discussing a profound transformation in the capitalist model, in particular through degrowth theories, does not, to our knowledge, cover the subject of the agroecological transition. Degrowth is nevertheless embodied by social movements supported by alternative agriculture models (cf. for example D'Alisa et al. 2014).
} 
in the making within our capitalist regime, to move towards a more sustainable agricultural and food system.

As this transition is currently underway, it is characterised by relative uncertainty because we cannot predict the end result (Lubello et al. 2017). The literature moreover refutes the idea that this agroecological transition is based on a single model positioned as the archetype of a new agriculture, instead defending the idea of the coexistence of a plurality of possible models that can contribute to greater agricultural ecologisation (Plumecocq et al. 2018). A major distinguishing feature of models supporting the agroecological transition is the representations and place granted to nature in the design of new solutions. The value attributed to nature underpins an ecologisation of agriculture that varies, depending on whether the new system aims at reducing its environmental impact or developing ecosystem services (Therond et al. 2017; Plumecocq et al. 2018).

The first route, which we called "weak ecological modernisation", aims at increasing the efficiency of synthetic input use (Horlings and Marsden 2011) through the implementation of standardised management practices (Ingram 2008) and the adoption of precision agriculture (Buman 2013) or genetic engineering technologies (Vanloqueren and Baret 2009). It can also be based on the replacement of chemical inputs by biological ones that are less harmful to the environment (Singh et al. 2011).

The second route, which we called "strong ecological modernisation", is based on a more radical redesign and significant biological diversification of agricultural systems (Kremen et al. 2012). It is characterised by intensified interactions with components of the biophysical system in order to substitute synthetic inputs by ecosystem services, and requires locally adapted agricultural practices and cropping or livestock farming systems (Duru et al. 2015b). This redesign of agricultural production systems is part of a broader change downstream to ensure sustainability across the entire agri-food system (Gliessman 2015). The recent literature also shows that food products strongly rooted in local production systems are those that address a broader range of sustainability concerns, whether in terms of biodiversity or ethics (Schmitt et al. 2017).

In this chapter, we focus on the agroecological transition following the route of strong ecological modernisation, broadened to include the question of food sustainability. To highlight the issues of this agroecological transition, two principles will structure our reflection:

(i) engagement of farmers and their advisers in building agroecological knowledge and techniques in situ to strengthen their capacities to change and to adapt;

(ii) territorialisation of agriculture, promoting a reconnection between agricultural production and local food, and enabling fair compensation of farmers for their activities.

However, as with any structural change, the stakeholders driving this transition are faced with the entrenchment of the incumbent model. Agriculture has progressively established itself as a coherent set of production and sales practices tied to the food industry (Meynard et al. 2015). For example, adopting a new pulse crop in crop 
rotations in a territory to reduce the use of synthetic fertilisers, strengthen crop biodiversity, and reduce greenhouse gas emissions, but can be hindered if consumers are not accustomed to eating pulses, or by a lack of transformation infrastructure, or of suitable supply circuits, ultimately leading to low pay for farmers. Those economic non-incentives do not encourage pulse farming (Magrini et al. 2016, 2018).

The aim of this chapter is to identify the broad range of concerns in transforming the values and techniques underpinning agricultural and consumption choices, in order to allow the stakeholders supporting this transition to build a governance approach adapted to these concerns. We draw on the literature on transition studies to identify the salient aspects and topics of interest regarding this agroecological transition.

This analysis is important, considering that little research on transitions has focused on the agricultural and food sectors (Picard and Tanguy 2016; Elzen et al. 2017). Moreover, most of the analysis scales used are still the territory, the production basin (Bui et al. 2016), or even an entire sector of agricultural activity (Elzen et al. 2011; Magrini et al. 2016, 2018), whereas the scale of the farm, which is nonetheless the central and essential link in any agroecological transition, tends to be overlooked (Chantre and Cardona 2014). This reflection will thus show that it is necessary to analyse the different variants of this agroecological transition on these different levels, from the agri-food system down to the farm scale, and that new conceptual and methodological developments in the fields of agronomy and system zootechnics are needed.

The first section goes over the theoretical foundations of transition analysis, in particular co-evolutionary approaches to sociotechnical changes, as well as their contribution to the analysis of the agro-ecological transition. Drawing on this theoretical clarification, the second section develops multiple topics of interest to explain the multi-dimensional nature of the agro-ecological transition, insofar as its implementation requires that the coherency of changes among a large number of stakeholders in the agri-food supply chain be taken into consideration. The third section focuses on several main issues on the farm level. The conclusion opens different paths for deeper analysis with respect to the governance of this agro-ecological transition.

\section{The Theoretical Foundations of Transition Processes}

The use of the concept of transition is relatively recent. It dates back to the nineteenth century, when it was used in different disciplines of the life sciences or social sciences and the humanities (Lachman 2013). For instance, Tocqueville used it to talk about the end of slavery; in political science, it initially designated the shift from socialist economies to capitalist economies; and it was used as the basis of some biology and population demographics publications. However, independent of its use, the word "transition" denotes a radical change of a systemic nature. Hence, transition approaches are focus primarily on deep-seated changes that very often 
affect both social and technical values, as opposed to incremental changes or innovations. The particularity of transition studies is that they highlight these interdependencies between social and technical values, justifying the central use of the concept of "sociotechnical" regime to describe a coherent set of stakeholders, knowledge, rules, values, and artefacts governing an incumbent production model (Elzen et al. 2004; Geels 2004).

Among the different heuristic frameworks of the transition towards sustainability developed in this literature, the Multi-Level-Perspective (MLP) framework is one of the most cited (Brauch et al. 2016; Chang et al. 2017). Drawing on several social science disciplines (including economics, sociology, political science), the MLP approach is multidisciplinary and integrative by nature, allowing one to address societal change through its multiple components and to convey the complexity of this change. This research focuses primarily on the conditions of the transition, from a society based on the intensive use of fossil fuels to one based on the use of renewable resources to satisfy various societal functions such as food, energy production, or transportation (Foxon 2011). Any societal function can be the subject of a transition. Lachman (2013) thus defines a transition as when "[t]he dominant way in which a societal need (e.g. the need for transportation, energy, or agriculture) is satisfied, changes fundamentally".

This systemic approach describes the mechanisms through which the target to achieve sustainability is confronted with a lock-in situation (section "Transitions are embedded in lock-in situations"), and the resources for the unlocking process that will initiate a transition (section "Unlocking in transition approaches"). The empirical literature on transitions specifically shows the importance of the conditions for the spreading of innovation niches in these processes (section "Scales and scopes of transition analysis: the major role of networks of stakeholders").

\section{Transitions Are Embedded in Lock-In Situations}

Sustainability transition approaches stem from the idea that the dominant production system (for example, in the sense of a supply chain, sector, or food system) is locked in (Geels 2004, 2011). The only changes within the incumbent system aim at improving it and therefore strengthening the technological trajectory initially chosen. Because they remain incremental, these changes do not permit a radical change (that is, a change in technological paradigm). This lock-in is strengthened by the fact that the routines and standards within which stakeholders operate hinder their creative capacity, and because the multiple dependencies between the technical and social components of the system have become reinforced over time. Several studies adopting this co-evolutionary approach enable us to understand how these lock-ins are constructed in the agricultural sector (Cowan and Gunby 1996; Vanloqueren and Baret 2009). For example, the work of Magrini et al. (2016; 2018) shows how the political drive following the Second World War, based on the 
conventional paradigm, ${ }^{3}$ discouraged the development of production alternatives with less use of mineral fertilisers, such as pulses farming. Instead, the specialisation of production by country (European cereals versus American soy), region, and farm, supported by the use of synthetic inputs and specific genetic changes, were promoted. Combined with market dynamics favouring certain species, the conventional regime strengthened the economic competitiveness of a few main crops as well as geographically-concentrated industrial livestock farming, to the detriment of agriculture based on agrobiodiversity and the integration of cropping and livestock (Horlings and Marsden 2011; Duru et al. 2015b).

Evolutionary economists explain this lock-in through the concept of "increasing returns to adoption". This key concept, coined by Arthur (1989), explains how one technology progressively "prevails over" the alternatives due to the fact that its performance improves by being increasingly adopted. Five main types of mechanism (called "self-reinforcing") feed this adoption practice and highlight the role of collective action and knowledge. These mechanisms are illustrated for the conventional agricultural paradigm in (Magrini et al. 2017; 2018). We give a brief overview of them below:

(i) learning by using: the production performance of synthetic inputs and selected varieties and breeds increases with user experience;

(ii) network externalities: the greater the number of adopters, the more beneficial it is for users to adopt the system to benefit from other products or services developed, such as services to support crop management, storage, and sale;

(iii) scale economies and learning by doing: the unit cost of production is reduced over time by the volume effect and the improvement of the techniques and materials developed, such as agricultural mechanisation;

(iv) informational increasing returns: the more this production paradigm develops, the more widely known and understood it becomes, thus incentivising others to adopt and develop it;

(v) technological interrelatedness: other production technologies and standards are established in the food sector in relation to this agricultural production, such as seed quality criteria for food transformation (e.g. grain protein content).

These returns to adoption are said to be "increasing" because, as a system develops more users, the utility for each user is increased compared to alternative solutions. Knowledge on the dominant system is progressively consolidated compared to alternatives, which are more uncertain because they receive less investment. Stakeholders in the agricultural sector in particular highlight this problem of uncertainty surrounding alternative crops (cf. Chap. 6). Hence, uncertainty surrounding alternative solutions, which have benefited from less investment and knowledge, as

\footnotetext{
${ }^{3}$ The conventional paradigm is often called the agri-industrial and agri-chemical paradigm due to the combined logic of a high degree of standardisation of agricultural production enabled by the accumulated use of synthetic inputs.
} 
well as the inherent cost of the change, reinforces the initial choice over time, that is, the conventional paradigm.

To unlock such a lock-in, it is necessary to understand all the components of the system that determine the triggering of a new trajectory which can be consolidated over time through these same mechanisms of increasing returns to adoption. The multilevel approach developed by Geels (e.g. 2004) offers a framework to understand how a new trajectory can begin.

\section{Unlocking in Transition Approaches}

This theory of technological lock-in has allowed for the renewal of approaches to change by highlighting the co-evolutionary nature of trajectories. Its analysis framework is however strongly focused on the role of technological innovation. The specificity of transition approaches has consisted in expanding this framework to consider the roles of a multitude of stakeholders, including civil society, and not only those using the technology (e.g. a way of producing). For example, new technological innovations can simultaneously trigger changes in scientific knowledge as well as in factors tied to the demand from civil society, in particular ethical factors. Many authors thus insist on the fundamental role of societal values, which legitimise production decisions (Plumecocq et al. 2018). The incumbent production system (e.g. the dominant sociotechnical regime) has built its coherency over time as a function of the progress of scientific knowledge, technologies and infrastructure, and networks of companies and markets. It has also based itself on values tied to consumer preferences and different institutions, defining a set of rules and standards structuring collective action (Elzen et al. 2004). As Geels (2012: 474) demonstrates, "an important implication is that the MLP does away with simple causality [...] there is no single 'cause' or driver. Instead, there are processes on multiple dimensions and at different levels which link up and reinforce each other".

The second specificity of the MLP approach is that it offers three main levels of analysis that influence one another and steer the evolution of the sociotechnical regime (i.e. trajectories), presented as a diagram in Fig. 1. Major evolutionary factors, such as demographic shifts or environmental problems affecting all societal functions, can place the sociotechnical regime in a situation of crisis if the principles governing it do not provide a solution to these problems. These societal contextual elements, which constitute the 1st level of analysis (called the "landscape" according to MLP terminology), open up windows of opportunity for radical changes. However, because the dominant regime (2nd level) does not constitute a space of radical innovation, the keys of the change operate on another level: that of innovation niches (3rd level of analysis). These innovation niches are built by stakeholders outside of the dominant regime. They enable the development of new ways of producing, transforming, or consuming in order to more radically address contemporary pressures on the landscape. When these niches reach a certain stage of development and internal structure, they can spread in the dominant regime. They 


\section{Increasing structuration \\ of activities in local practices}

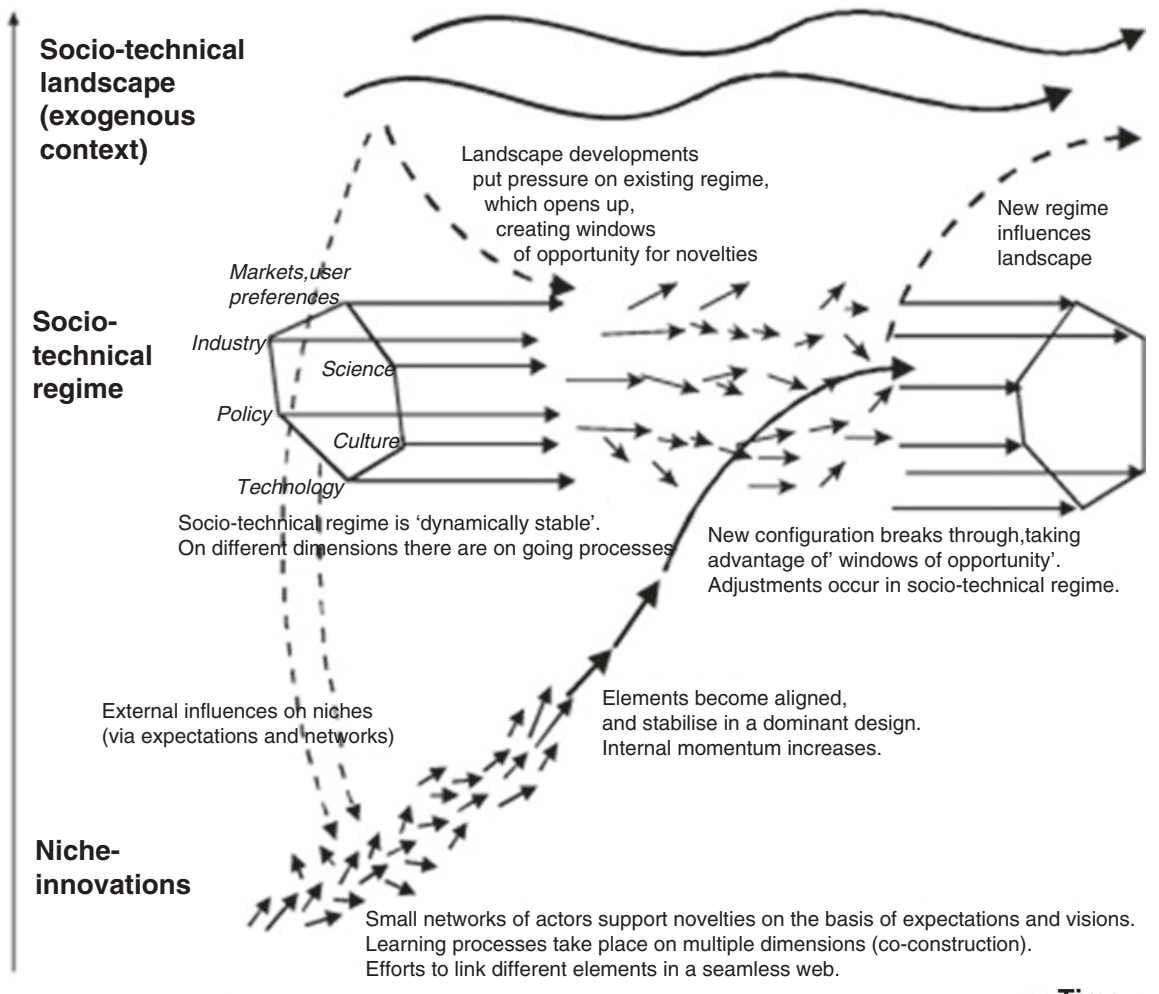

Fig. 1 The MLP approach to transitions (in Geels 2011)

The MLP approach is based on 3 levels of analysis: the landscape, the dominant sociotechnical regime, and innovation niches representing networks of stakeholders oriented towards radical innovation. The transition process encompasses all interdependencies that are woven between these 3 levels over time

can then choose between two main strategies: submitting to the selection factors of the dominant regime ("fit and conform") or trying to modify them ("stretch and transform") (cf. Smith and Raven 2012 for more details).

Organic agriculture is an emblematic example of this process: its network of stakeholders established itself progressively and is now spreading within the dominant regime. For example, organic products are now sold in large retail chains and the rate of conversion to organic has increased over the past few years in France. Yet organic has not managed to reverse or replace the conventional regime, which remains dominant. It is by obtaining a quality marking that differentiates it on the market, that organic products are able to economically develop under the conditions of the dominant regime. The specific aid for conversion provided by Europe is also evidence of 
a change starting in the dominant regime. Hence, the organic innovation niche has progressively become a market niche and continues in itself to be an incubator for new practices prohibiting synthetic inputs that influence the dominant regime.

Many hypotheses support the role of niches as incubators of radical innovations: for instance, whereas their development outside of the dominant regime promotes the emergence and expression of new creative capabilities not limited by the routines and standards of the dominant regime, within that regime the initiation of economic activities by new entities is less hindered when taking risks (which are often prohibitive for established players that want to secure margins or pay off specific investments tied to already-established activities). In the MLP approach, the process of the change in the dominant regime starts, strictly speaking, when niches manage to spread within the regime and to influence its evolution around its major components (the stage of the "empowerment" innovation niche, in the sense of Smith and Raven 2012. This leads to a new alignment of the trajectories of different components of the regime (details in Fig. 2). The MLP framework is thus a fundamental co-evolutionary and diachronic approach.

This heuristic framework for transitions, which was developed in the 2000s, has been extended many times. This highlights the complexity of the processes of spreading innovation niches within the dominant regime to initiate a change in trajectory, drawing in particular on the work of Smith et al. (2005), Smith and Raven (2012), and Raven et al. (2016). Various configurations are possible, depending on the type of ties maintained between niche and dominant regime stakeholders. There is often an overlap of networks of niche and regime stakeholders, as certain stakeholders are present in both systems. This is particularly manifest in research on the agricultural sector, in which the sale of agricultural products does not necessarily benefit from alternative transformation and distribution networks. In other words, differentiated products can be distributed by dominant networks, with alternative networks remaining on the sidelines. For new practices to spread there must therefore be a minimum level of adaptive capacity in the dominant regime - and

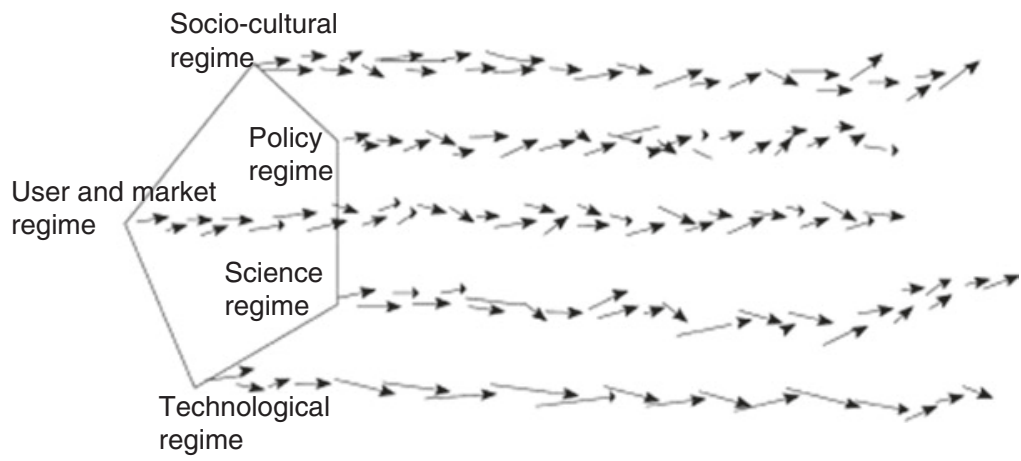

Fig. 2 The alignment of trajectories in socio-technical regimes in Geels (2004)

The sociotechnical regime is composed of multiple subsystems whose trajectories align with one another, providing coherency to the whole regime 
vice versa in the niche, in relation to the dominant regime. These two levels of analysis (regime versus niche) of the MLP approach must therefore be analysed together. This is why (Ingram 2015, 2018) proposes an "overlapping niche-regime space" rather than separating these two entities, as the MLP approach suggests.

Elzen et al. (2017) more particularly focus on the role of stakeholders that are intermediaries between the dominant regime and innovation niches. These intermediary stakeholders, called hybrids, are described as participating in an innovation niche while simultaneously having direct access to the dominant regime (for example, through their participation in debate arenas or by holding positions at dominant regime stakeholders). They can also be "innovation brokers" that promote interconnection between the dominant regime and niches, and which are highlighted as essential stakeholders in these transition processes (Klerkx et al. 2012). For example, the research of Bouttes et al. (2018) reveals the major role of these stakeholders in the case of conversion to organic agriculture: for livestock farmers, the fact that the agricultural adviser supporting them was previously a part of the conventional system (at a chamber of agriculture) is a guarantee of credibility and legitimacy.

\section{Scales and Scopes of Transition Analysis: The Major Role of Networks of Stakeholders}

Transition processes require us to consider multiple scales of analysis - whether the temporal (start and duration), geographic, or sectoral scale - in relation to the scope of the network of stakeholders observed.

The majority of research insists on the emergence and initial stages of these processes, granting particular attention to the structuring of innovation niches. Some focuses more particularly on the emergence of the niche, which can be based on different strategies varying in their distance from the dominant regime. These configurations of ties between niches and the regime vary, as indicated above (Ingram 2015). For example, conservation agriculture is outside of the domain of the dominant regime in order to allow stakeholders to develop their ideas and experiment freely (Vankeerberghen and Stassart 2016). In contrast, stakeholders in the BleuBlanc Coeur supply chain chose to include themselves in the dominant regime from the emergence of the niche, to quickly access financial resources and allow it to spread faster (Magrini and Duru 2015; cf. also Elzen et al. (2008) or Diaz et al. (2013) concerning anchoring strategies). Different stages are often highlighted in these transition processes. In their analysis of the development of niches directed at structuring local food systems, Bui et al. (2016: 99) identify three key stages in a transition process: "the emergence of the initiative (Stage I); the construction of a sociotechnical niche through the enrolment of new stakeholders into the initiative, leading to the diversification of objectives and activities (Stage II); the construction of an alternative model impacting various components of the agri-food regime (Stage III). The increasing diversity of stakeholders involved in the niche progressively leads to the construction of an alternative model, and the enrolment of local 
authorities, through spill-over effects, then triggers deep changes in practices, strategies and alliances of some regime stakeholders at the local scale" (page 99). The evolution of the network of stakeholders structuring the innovation niche allows them to access resources and, to a certain extent, determines their development up until the empowerment stage.

These publications show that an increase in the number of stakeholders involved in the process is a necessary condition of the transition. Increasing the size of the network of stakeholders makes it possible to progressively establish ties with certain stakeholders in the dominant regime. By participating in exchanges with niche operators, the dominant regime will be able to understand the stakes and opportunities of the development of the niche, and will push towards its own reconfiguration. These intermediary stakeholders constitute relays between the niche and the dominant regime. They often enable access to public policy resources to help to develop the niche and spread innovative practices. For example, the structuring of certain locally-based food systems can involve local officials in the development of these niches in order to access new support devices (cf. the example of Bui et al. 2016). Another example of the role of political stakeholders is the policy of the city of Mouans-Sartoux in France. By organising the supply of school cafeterias with local organically-produced products, the elected officials of this commune have been successful in structuring and perpetuating a network of stakeholders around this innovation niche (Pérole 2017).

The social interactions that take place within niches or in relation to the dominant regime are thus at the core of transition processes. It is therefore useful to grant particular attention to devices aiming at establishing a consensus between stakeholders regarding visions of changes to carry out and possible routes for achieving common goals. This is precisely the goal of the TATA-BOX project, through carrying out a territorial diagnosis followed by phases for designing, evaluating, and selecting agro-ecological transition scenarios (cf. Chap. 9). Among these devices, "transition arenas", defined as spaces of shared dialogue between stakeholders engaged in moving towards a change in the system (Boulanger 2008), constitute an essential structure in the transition process (Duru et al. 2015b). Networks of stakeholders built through these arenas are fundamental in the transition process, because by "building up a broadening network of diverse actors that share the debate, thinking and experimenting, conditions are created for up-scaling of innovation and breakthrough of innovations" (Loorbach and Rotmans 2010: 238). These authors thus emphasise that in a transition process, "we need both pioneers operating outside and inside the incumbent power structures" (ibid.: 243). For example, the RIO project in the Netherlands, based on the creation of a reflexive arena to rethink livestock farming systems, has enabled significant progress in establishing a consensus of new ideas among livestock farmers, supply chain stakeholders, and consumers (Bremmer and Bos 2017 in Elzen et al. 2017).

The scope of the transition process also depends on the sector in question. In agriculture and agri-food, two main situations can be distinguished, depending on whether the agro-ecological transition is mainly based on a departure from the dominant regime in terms of production methods with little engagement of the down- 
stream, or whether it is embedded within a larger transition of the food system (Therond et al. 2017). In the first case, the agricultural products are not distinguished from those of the dominant regime; they are often sold at global market prices. There is no distinctive quality marking, even if production methods are more respectful of the environment (e.g. grass-fed livestock, conservation agriculture). It is the relationship to the upstream that is changed through decreased input consumption or equipment needs. In the second case, beyond production methods, the transition includes a diversification of production (crops, animals, etc.), a modification in input supply, both in the choice of inputs and in the ways of accessing these resources, and new organisations in product collection, storage, or transformation, as well as in consumers' food habits.

From the time perspective, transition researchers agree that processes underway on the societal or industry level are staggered across a 25 to 50 year period and therefore involve one to two generations (Elzen et al. 2004, 2011; Geels 2004; inter alia). However, this period can be longer, depending on the extent of the change considered. Sovacool (2016) thus believes that while studies analysing the adoption of a new technology intended for consumers (such as the refrigerator or digital technologies) fit within short timeframes (around 25 years), transitions concerning indepth changes (such as large energy or transportation infrastructure) take place over longer periods (from 50 to 100 years). While authors analyse transitions ex-post by retracing the history of these processes over several decades, the majority of studies on transitions in the making present the state of these processes over shorter time periods and, generally speaking, over 5- to 15-year intervals, such as in the work of Elzen et al. (2011) on pig farming, Diaz et al. (2013) on green algae in Brittany, or Lascialfari et al. (Forthcoming 2019) on product innovation in the agri-food sector. These long intervals concern situations in which the transition requires getting a large number of stakeholders in the food supply chain on-board. By contrast, independent of the timeframes observed on the societal or industry level, a farm can implement the transition over much shorter intervals of only a few years when changing its production system or the way that it sells its products.

This review thus allows us to propose that the combination of these multiple changes (or their alignment, in the words of the MLP framework) a fortiori prefigures the different possible trajectories of the agroecological transition. While different trajectories are possible, we continue to use the term "agroecological transition" (AET) to refer to these change processes as a whole.

\section{What Are the Determinants of the Agroecological Transition on the Scale of the Agri-Food System?}

Considering the multidimensional nature of the AET and the fact that it involves a large number of stakeholders upstream and downstream of agriculture, below, we highlight a few of the noteworthy features of changes underway that predetermine 
(or will predetermine) agroecological transition trajectories. We start by considering the importance of shared values, in particular those of farmers and consumers, so necessary to supporting the AET (section "What are the values underpinning the AET?"). We also show that various innovations related to transformation and sale infrastructure for agricultural productions (section "What new market infrastructure provides the basis for AET?") have a significant influence on the AET. Lastly, we analyse the role of technical norms and standards in institutionalising the AET, or in the making of new collective action rules that can support the AET (section "On what new collective rules is AET based?").

\section{What Are the Values Underpinning the AET?}

Social values are one of the bases of collective judgement governing the acceptability of individual or collective choices and decisions. For an individual, adhering to social values means recognising oneself as a member of a greater community based on moral principles. In this sense, our food choices pertain to worldviews varying in their degree of tacitness or implicitness, and in the extent to which they are owned or asserted. These worldviews relate to ethical or moral motives, amongst others, in such a way that food systems, which constitute interfaces between farmers and consumers, as well as markers of cultural identity, are excellent observation posts to understand the role of values in the agroecological transition.

Consumers' food choices are based on various lifestyle-related types of values. In Western countries, the topic of diet is currently crystallising around protein consumption concerns. Abandoning a diet mainly based on animal protein derives from a variety of overlapping values today - environmental concerns, ethics in terms of animal well-being, nutritional or economic values: Amongst these, environmental or health-related values appear not to be foremost in the minds of consumers, despite the fact that they are stressed by scientific experts (Campbell 2009; Hartmann and Siegrist 2017; de Boer and Aiking 2018). Scientists now agree that it is necessary, in terms of the health of individuals and the planet, to balance animal and vegetable protein sources in our diet: "there is broad consensus that reduction of meat consumption will be crucial for a transition towards more sustainable food consumption" (Hartmann and Siegrist 2017: 12). This is driving experts to highlight food information and education to change the values underpinning consumption choices: "in order to move towards more sustainable food behaviour, consumers and citizens need to have better knowledge about the environmental consequences of their food behaviour. Otherwise, it will be unlikely that consumers will be motivated to change their food behaviour" (ibid.: 22). In France, decreasing animal product consumption was recently included in new food guides (Anses 2016), but remains to be implemented at the level of food education programmes.

Lastly, the stakes involved in the AET require us to rethink the ways that interests and values can be combined to continue to ensure compensation for sector stake- 
holders, all the while meeting new social standards. To this end, an increasing number of consumers are willing to pay an additional price to assert their values by supporting agricultural activities that embody them (for instance buying products with "organic agriculture" labels or supporting small-scale family farming). Opinion polls tend to indicate that civil society recognises the difficulties inherent to farming (strenuousness of the work, low pay, etc.), which explains why, in 2016, "despite a context of economic crisis, which is usually restrictive for the consumption of households, two thirds of French people said that they were willing to pay more for products to ensure fair payment to farmers" (Gomant 2017: 15). A set of values (expressed in terms of social justice or solidarity) is thus driving a transition to a societal model in which the living and working conditions of farmers are expected to be better. The perception of deep-rooted imbalances in the distribution of added value in supply chains, which increase as supply chains get longer (Brown et al. 2013; Schmitt et al. 2017), has encouraged the organisation of multiple business initiatives driven by the values of fair trade (Therond et al. 2017). This need to overhaul the agricultural social model was stressed by the Etats Généraux de l'Alimentation ${ }^{4}$ in France, in 2017.

The modalities of food distribution in supply chains, as well as ways of indicating product qualities, closely reflect the value systems underpinning them. The increase in consumers' preferences for local production places value on regional products (cf., for example, the BVA-INRA survey on the durum wheat supply chain, Triboulet et al. 2018). This leads us to consider the implications of changes in the organisation of the transformation and sale of agricultural products (section "What new market infrastructure provides the basis for AET?").

\section{What New Market Infrastructure Provides the Basis for AET?}

The theory of increasing returns to adoption shows that the logic of economies of scale has supported the development of large-scale collection, transformation, and distribution infrastructure (Magrini et al. 2016, 2018). Even when these economies of scale are not "economically" achieved, stakeholders' belief in this principle has encouraged the geographic concentration of infrastructure over time. For example, in the meat sector, the research of Soufflet (1990) shows that over twenty years (1967-1987), slaughterhouses for cattle were not profitable even though they had been concentrated and increased in size. Considering a spatial redistribution of storage and transformation infrastructure does not necessarily imply a financial loss,

\footnotetext{
${ }^{4}$ The États Généraux de l'Alimentation was a convention initiated by the State President in 2017 with the purpose of collectively building new, sustainable, food and agricultural systems, on a "win-win" basis. It was based on broad, nation-wide public consultation, as well as over 20 workshops where experts came together to draw up proposals. This work was continued in 2018, primarily through the enactment of a new Agriculture and Food law.
} 
because economies of scale are often decreasing, starting from a certain production and concentration threshold. Moreover, the industrial concentration of certain groups often leads to distancing from production basins, which "become anonymous". Distributing infrastructure across the territory could promote territorial reconnection between agriculture and food in order to more directly valorise the diversity of crops farmed in territories.

As mentioned above, French consumers tend to want more local food rooted in their region. To meet this demand, large and medium-sized supermarkets, which are still the main place of purchase in Western countries (90\% of food purchases in France), must develop their offering of regional products and therefore need to reorganise their purchase centres and logistics circuits. The development of short circuits, such as AMAP (small-farmer associations), direct sale, or local markets also aims at meeting this demand. These alternative consumption relays are making significant progress in France. According to the results of a recent survey, 42\% of respondents had purchased a product from a short circuit over the past month. Once again, the shift in consumer values can orient the evolution of these distribution networks and lead farmers to rethink their ties to consumers.

The catering industry is an ideal place for promoting these connections. Recent experiments show that it is possible to develop a diet based on local production, but that this territorial transition takes place over a long period of time. In his text on Mouans-Sartoux (in the south-west of France), Pérole (2017) explains how this city, which decided "to reconquer its food sovereignty", undertook a number of measures starting in 1998 that allowed it to become, in 2012, "the first commune in France with more than 10,000 inhabitants to switch to $100 \%$ organic in its cafeterias" based on quasi-local production. In 15 years, owing to the determination of the local council, this city has implemented a number of changes, such as buying back agricultural lands, aid for converting farmers to organic agriculture, developing a municipal public company to prepare meals itself, and training cooks on how to cook with local products. The learning carried out and the internal reorganisation of production has ultimately made possible an agroecological meal price that implies no extra costs. Consumption values and habits have also changed in the targeted population, since the surveys carried out by this city show that in 2014, 66\% of parents surveyed "believe that their own food habits have changed towards more organic and local", whereas this number increased to $85 \%$ in 2016, almost 20 years after the initiative to engage this city in an agri-food transition.

This example also shows that stakeholders can decide to include a new activity, to achieve their goals, or to develop new hybrid methods for organising exchanges between the market and the hierarchy. Production contracts are organisational bases that facilitate these change processes, particularly to secure new investments (Cholez et al. 2017). They also promote the structuring of new spaces for dialogue between operators, encouraging knowledge exchange to reduce the uncertainty underlying the change (cf. Chap. 6). 


\section{On What New Collective Rules Is AET Based?}

The evolution of the norms and standards structuring collective action is just as important on the consumer side of things as on the farmer side. Standards or certifications remain an essential tool for disseminating new rules and information, especially in the agri-food sector (Mazé 2017).

On the consumer side, the recognition of the agroecological practices associated with a product can allow consumers to orientate their consumption choices. However, confusion tends to prevail today in the information directly accessible to consumers or not. Magrini and Duru et al. (2015b) recall that the absence of specific labelling for livestock farming conditions in France makes it impossible for consumers to make choices based on virtuous practices such as grazing. This is despite the fact that in the United States a label certifying farms where animals are exclusively grass-fed (Grass Fed Label) has existed since 2009. Even if new certifications are implemented, their quality has to be assured. Hoibian (2010) reports that "only $31 \%$ of people believe that the information on 'green' products has a scientific basis" and only " $25 \%$ find it clear". The increase in ecological claims surrounding massively-consumed products ("100\% natural", "respectful of the environment", etc.) reinforce suspicions of "greenwashing".

This calls to mind the current strategy of supply chains that are demonstrating a tendency to increase "agroecology" certifications. A recent study by Lhoste (2017) shows that many existing labels (e.g. "Nature et Progrès", "Bleu-Blanc-Cœur") currently tend to claim that they are agroecological, based on different principles in each specific case. This proliferation of food standards increases consumers' confusion and "risks resulting in additional costs to producers and limiting access to markets" through competition effects (Meybeck and Gitz 2017).

On the farmers' side, labelling based on agri-environmental criteria can also help to change the focus of their decision-making by granting more priority to environmental criteria than to yield criteria. This institutional framework is even more important, given that conversion to agroecology can result in a decrease in yields over the short term (Weiner 2017). Therefore, the development of standards or new practice measurement indicators is also a concern for farmers. Today, many initiatives exist to promote the development of new performance measurement indicators. For example, beyond organic agriculture standards based on method requirements, multiple attempts to develop new certifications are currently being tried out in France (such as HVE - Haute Valeur Environnementale (high environmental value) - or the IDAE method - Indicateurs de Durabilité des Exploitations agricoles (farm sustainability indicators)). Nonetheless, confusion can be just as pervasive among farmers and their advisers. It is therefore essential to find a relevant balance between recommendations and minimum obligations to promote improved environmental performance and better product composition. More recently, the Etats-Généraux de l'Alimentation (cf. above) carried out by the French government suggested generalising an HVE certification label that would be more comprehensive and integrate a degree of agricultural territorialisation. Ultimately, the new 
label or labels that will be introduced could accelerate the transition process if they earn consumers' trust.

Finally, note that the institutional framework can also be based on other regulation devices that also merit analysis, such as public payments to farmers, either to offset lower agricultural income, as in Switzerland (Schmitt et al. 2017) or to compensate for agri-environmental services (Reed et al. 2017). Through this system, consumers compensate farmers primarily through taxation rather than through prices, thus promoting food consumption that is less dependent on consumers' incomes.

\section{The Determinants of the AET on the Farm Level}

As mentioned above, few studies have carried out an in-depth analysis of an AET processes on the farm scale, whereas this is a key organisational level in the AET process. In this research, the farm is considered to be embedded within an agri-food system and an agricultural development system making up the incumbent sociotechnical regime. The AET of the farm therefore takes place through the reconfiguration of the interactions between the different components of the regime: "changes in farming practices are contingent on a profound reconfiguration of the whole agri-food system, i.e. change in the practices and modes of coordination of all incumbent actors - farmers, processors, distributors, consumers, public policies, research and extension services" (Bui et al. 2016: 92). This research shows the need to design coupled innovations that promote interactions between the farm and supply chain operators (Meynard et al. 2015, 2017). Yet the literature on transition in agriculture has seldom analysed the transition processes at work on the farm and among farmers.

In particular, it is very interesting (and necessary) to analyse farmers' adaptive capacities. These are defined as being aptitudes with respect to designing and implementing adaptations or changes and managing new situations without compromising future options (Nelson et al. 2007; Marshall et al. 2014). They largely depend not only on farmers' personal traits (in terms of risk perception, values and goals, attitudes and beliefs, integration within collective dynamics) (Moser and Ekstrom 2010), but also on the prospects of the agricultural system with respect to the natural, physical, human, financial, and social capital of the farm (Nazari et al. 2015). In this section we emphasise the features of these adaptive capacities in the context of the AET of the farm. We start by focusing on farmers' values, aims, and attitudes (section "Triggers of the AET for farmers: values, aims, and attitudes"), later turning to their perception of the risks associated with the AET (section "Farmers' perception of risks and uncertainty with regard to the transition"). We then address their learning dynamics for and during the AET (section "Farmers' learning for and during the AET") and how innovative support devices can contribute to this (section "Reconfiguring exchange networks and "advisory" devices: is a shift towards a new regime of agricultural knowledge taking place?"). Finally, we discuss how the 
technological innovations (section "Using technological innovations to aid the AET of farms") may promote the AET of the farm.

\section{Triggers of the AET for Farmers: Values, Aims, and Attitudes}

Changing values around food consumption and diet are driving agricultural production systems to change. Organic agriculture, for instance, has made considerable progress over the past years, and in 2015 and 2016 in France, increases in consumption and certified organic surface areas were $21.7 \%$ and $17 \%$, respectively. Analysing farmers' AET processes reveals that the values or motives behind these processes vary. Recent surveys show farmers' growing interest in reducing the use of phytosanitary products. ${ }^{5}$ Their motivations are both extrinsic (opportunities related to the development of a market and a growing demand for these products) and intrinsic (return to more "agronomic" practices, desire to preserve ecosystem resources, limit pollution, respect nature, etc.) (Plumecocq et al. 2018), and potentially support the AET. Certain motivations also relate to expectations surrounding working conditions. For example, the transition of cattle farmers to grazing systems is partially related (Lusson et al. 2014; Cayre et al. 2018) to the amount and nature of the work (e.g. "doing something other than riding a tractor"). The motivations behind the change can also be related to a renewal in the societal function (environmental, health, or ethics) of livestock farming (e.g. "producing healthily to eat healthy") and to technico-economic motivations (savings on inputs). Four main triggers were identified that encouraged dairy farmers to transition towards agroecology: evidence that it was possible to earn a living after adopting breeding practices that generate less milk yield; finding that they were stuck in technical ruts; differences between farmers' values and practices; and external incentives or requirements (Coquil et al. 2017). The transition allowed these livestock farmers to overcome difficulties while more closely following personal and societal aspirations (ethical values), even if this meant not following the standards recognised by the profession in the dominant regime. For some farmers, the AET thus represented a hope of working conditions more satisfying on the professional level, allowing them to better align their aspirations and daily reality with society's standards (Dessein and Nevens 2007; Barbier et al. 2015).

Farmers' attitudes regarding change management (aversion vs. appeal, positive vs. negative viewpoint) were an important component in the AET. On the one hand, the ability to face the changes was related to their psychological disposition (in particular risk aversion) and their ability to manage the impact of those changes

\footnotetext{
${ }^{5}$ The findings of a survey by BVA (2015) show that $76 \%$ of farmers implement initiatives to reduce inputs, $45 \%$ say they have heard of agroecology and are interested in this initiative, and $40 \%$ implement innovative initiatives defined as practices "that are not commonly used", such as biocontrol, crop associations, or the insertion of legume crops.
} 
(Marshall et al. 2014). A key factor in the success of farm transitions was the farmer having a proactive approach to the change while remaining attentive to global changes, the alternatives offered, and the various possible consequences (Coquil et al. 2014; Chantre et al. 2015). It was also beneficial to engage actively in the change rather than perceiving it as being costly or risky and thus enduring it. The situation prior to the transition was another determinant of the ease with which farmers would implement this transition. In the case of conversion to organic agriculture for dairy farming, Bouttes et al. (2018) emphasise the psychological tensions experienced by farmers at this stage: they were facing a very low price for conventional milk and they had a large workload following the increase in farm size (by seeking economies of scale to amortise investments).

\section{Farmers' Perception of Risks and Uncertainty with Regard to the Transition}

Farmers' perception of risks also affects their capacity to change. This dimension is even more important considering that the changes to be implemented in an AET are complex and uncertain for multiple reasons (Duru et al. 2015a, b): (i) they are systemic; (ii) they are based on capacities that farmers may have lost (for example, efficient grazing management); (iii) they are highly dependent on local conditions, which means that farmers must adjust the nature and extent of these changes based on their production situation; (iv) they are uncertain because the response of the agroecosystem to new management practices is poorly known in advance; (v) they must correspond to local socio-economic opportunities (for example, a dairy that wants to purchase organic milk) and threats; and (vi) they must adjust dynamically to changes in the production context.

Even if farmers perceive the AET as a risky and uncertain process, their capacity to perceive other risks can engage them in a shift in practices. For example, one reason for dairy farmers to convert to organic agriculture is the perception that there are fewer risks and less uncertainty in the future of organic dairy farming than in that of conventional dairy. This is because farmers believe that over the short and medium term, organic milk prices will be more stable and consumer preferences more favourable (Bouttes et al. 2018). Another reason for change is related to controlling market risks. Conversion to organic agriculture increases farm autonomy, which reduces exposure to the volatility of input prices. On the other hand, it can constitute a significant risk, often due to a lack of technical knowledge (Padel 2001). When deciding to undertake such a transition, farmers evaluate compromises between external factors such as product quality requirements, regulations, and prices, and internal requirements, such as risks related to new production techniques (Lamine 2011; Chantre and Cardona 2014; Bouttes et al. 2018). 


\section{Farmers' Learning for and During the AET}

AET requires farmers to develop their learning capacity for practices that differ from those of the dominant system and with which they are mostly unfamiliar (Darnhofer et al. 2010; Marshall et al. 2014). This relates to their capacity to design/ create alternative management methods in situ, to test and experiment with them, and to evaluate these experiments in order to derive lessons from them (Chantre et al. 2015). Furthermore and more generally, it relates to a variety of processes that can lead farmers to develop pragmatic judgements (Cristofari et al. 2018). Individual creativity in managing farm resources (the soil, plants, animals) relates to the way that this management integrates local pedoclimatic potential as well as the biological potential of animal and plant resources as perceived by farmers. For example, certain dairy farmers crossbreed within their herd to create genetic types that are more suitable for local feed resources and to meet their objectives (Ollion et al. 2018). These changes in practices involve at least three new management entities: (i) the management of plant and animal agrobiodiversity (Martin and Magne 2015; Magne et al. 2016, 2017; e.g. crossbreeding rotation types, the aptitudes and complementarities of breeds); (ii) managing integration between plant and animal production to reconnect the plant-soil-animal triad by closing biogeochemical loops (Bonaudo et al. 2014); and (iii) managing contact between domestic and wild fauna (Charrier et al. 2017) and production and sale (Nozières et al. 2014). Farmers are then led to move away from the professional standards and references of the dominant regime that regulated their initial practices (Meynard 2017). In particular, this includes revising the concept of performance in agriculture (Caron et al. 2014)). For example, accepting a decrease in the volume of milk produced per cow below a certain level (approximately 5000 to 6000 litres of milk) is not easy for many farmers converting to organic agriculture, whereas this is nonetheless an essential factor in the success of the conversion (Bize 2017). This departure from prevailing professional standards and references implies the creation of other evaluation and steering benchmarks for farmers. It is a key phase in their learning process as a part of the AET (Chantre et al. 2015). In addition to the intentional experiments that they carry out, farmers can also make use of unforeseen events by transforming them into a learning opportunity, which becomes more interesting as the uncertainty becomes greater (Cristofari et al. 2018). Most often, these benchmarks are not established in isolation at the farm but within a group of farmers (Chantre et al. 2015). Therefore, as many studies have shown (e.g. Bouttes et al. 2018), farmers can experience the AET as a welcome opportunity for learning, escaping from their routine, and facing a new challenge. Maintaining such an experimentation and learning dynamic is essential if they are to adapt to changing economic, social, and ecological conditions beyond the transition phase (Vogl et al. 2015). 


\section{Reconfiguring Exchange Networks and "Advisory" Devices: Is a Shift Towards a New Regime of Agricultural Knowledge Taking Place?}

Agroecology is based on renewing knowledge on agricultural techniques by drawing more on farmers' knowledge (Warner 2007; Meynard 2017). Local experiments within different knowledge exchange communities are devices to create and spread agroecological knowledge. Analysing the features of these communities in depth allows us to understand what determines the capacity of these communities to promote the spreading of new knowledge and practices (Ingram 2018).

Beginning an AET implies that the farmer has taken a step back from the technical advice that goes hand-in-hand with purchasing inputs, and with respect to dominant technical benchmarks and standards. This distance allows farmers to build or join other networks of stakeholders (peer networks as well as farmer adviser/facilitator networks) that are in phase with the production methods being implemented (Chantre and Cardona 2014; Coquil et al. 2014). These peer exchange groups, which may or may not be hosted by an "adviser", facilitate creativity, reassurance faced with the uncertainty over the expected results, the building of a new framework of reference for action, and underlying values and reflexivity. In doing so, they facilitate the learning process (cf. Olsson et al. 2004), the management of risks and uncertainty, and the alignment of values and practices (Plumecocq et al. 2018). Therefore, learning and experimentation are largely promoted via a collective process in which production methods are proposed and discussed, ideas are integrated, practices are implemented at individual farms, and results are discussed in groups (Lamine 2011). These exchange devices are used in particular in the networks resulting from niches (Groupements d'Agriculteurs Biologiques (organic farmer groups), Centres d'Initiatives pour Valoriser l'Agriculture et le Milieu rural (centres for initiatives to develop agriculture and the rural space), etc.) and in instances of production under contract supported by strengthened advisory services and farmer field days on farms (Cholez et al. 2017).

These networks of stakeholders isolated from the dominant system (niches) constitute learning networks, i.e., privileged spaces for experimenting with and progressively spreading novel knowledge and practices to the dominant sociotechnical regime (Ingram 2015, 2018): "By taking a different innovation and learning direction, niches, through the actions of their knowledge systems, challenge the dominance of the AKS [Agricultural Knowledge System], and seek to change it through diffusion of more radical ideas and practices" (Ingram 2018: 3). This innovation dynamic is based on the AKS regime (Agricultural Knowledge System), in which knowledge production is primarily built around relations between "all relevant knowledge producers and stakeholders, including the farmers" (van Mierlo et al. 2017: 9). It differs from the KBBE (Knowledge-Based Bio-Economy) regime, in which knowledge production is primarily based on combining "life science with techno-scientific innovations to develop the means for an efficient use of agricultural resources" (Levidow et al. 2012; van Mierlo et al. 2017 cited in Elzen et al. 
2017). These two postures define two types of knowledge production regime, through which niches conveying novel knowledge are likely to be integrated in different ways into the sociotechnical regime.

The case of selecting and evaluating varieties illustrates the existence of these two knowledge production regimes, and namely: (i) a dominant regime founded on the selection of lineages carried out by seed companies operating across very large geographic scales that tend to homogenise knowledge; and (ii) an innovation niche founded on selecting populations adapted to the local context through seed exchange between peers (country seeds network), primarily based on situated knowledge. While today, these two regimes tend to oppose one another, it is possible to imagine a process to hybridise these knowledge regimes in the context of a transition, in view of the values driving them (Fenzi and Bonneuil 2016).

The reconfiguration of knowledge regimes also calls into question the place that agricultural education could occupy in constructing this new knowledge, for example with respect to the education system's adaptive capacity to integrate knowledge established in these communities of practices or in agricultural innovation networks (Simonneaux et al. 2016). This adaptive capacity remains largely tied to actor networks that are structured between advisors and these niches (Ingram 2015).

\section{Using Technological Innovations to Aid the AET of Farms}

While the AET aims at developing practices to provide ecosystem services, this does not mean that it uses no technological innovations. Identifying needs for technologies necessary or favourable to the AET is a major research concern (Therond et al. 2017). For example, selecting plant species or varieties that provide ecosystem services (e.g. soil structuring or coverage), or genetic animal breeds suitable for developing plant diversity (e.g. through greater ability to move around while grazing) remain priority research pillars to facilitate the AET. This is also the case for self-guided autonomous hoeing or parcel weeding robots that do not use phytopharmaceutical products. Progress in robotics may promote the farming of certain diversification plants (e.g. weeding crops with little coverage) or may free up farmers' time during their routine activities, thus increasing their involvement in other tasks. There are many examples of advances in robotics that can assist the AET, and agriculture has become the second largest market for professional robotics services (Bellon-Maurel and Huyghe 2016). Yet, with a view to achieving the best possible remuneration for farmers and reducing agricultural labour, the utility of these technologies must be considered with respect to the global cost of adopting new technologies.

Another type of technological innovation concerns knowledge capitalisation. As noted above, the changes needed to implement an AET are complex, situated, and uncertain for farmers. Information and communication technologies can contribute to understanding this complexity and reducing the uncertainty associated with it by making use of automatic data collection and processing. This is becoming more 
significant as calculation capacities become stronger (Bellon-Maurel and Huyghe 2016). Combined with these massive new datasets, the development of serious games such as Rami Fourrager ${ }^{\circledR}$ (literally, Forage rummy) (Martin et al. 2011) allows farmers to use simulations to design and evaluate alternatives to their strategy and current practices. Another example is the GECO application developed in France (Soulignac et al. 2017), which allows farmers to formalise knowledge and make it available or discuss it within the broader community.

The contribution of technological innovations to the AET is therefore largely a function of their capacity to promote the construction of agroecological knowledge and practices. These technological innovations are also fundamentally dependent on farmers' capacities to adopt them or to integrate the results of these technologies into their decision-making systems.

\section{Conclusion}

Without aiming to be exhaustive, this chapter has highlighted a set of concerns and determinants around which various agroecological transition trajectories could develop. Note that this transition takes place over time intervals that vary, depending on the analysis scale used (the farm or the agri-food system as a whole), but it combines changes in food and agriculture to achieve the goals of sustainable food, according to the definition of the United Nations.

By focusing on a plurality of factors and stakeholders at work in these processes, we have presented the complexity of this transition, particularly in view of the interactions that develop between innovation niches and the dominant sociotechnical regime, as well as the capacity of stakeholders to develop and spread new practices. We have specifically emphasised the role of the values that can orient these different processes, as well as individuals' abilities to adapt to the change.

This complexity at work therefore makes it necessary to implement support methods on different scales, to help stakeholders to design and execute the necessary changes. We propose to conclude this chapter by mentioning a few concerns specific to the issue of transition governance.

First of all, the shift in values associated with the transition shows that it is still necessary to create space for debate. The idea is not to create a uniform and shared vision but rather to democratically resolve controversies, the diversity of which may potentially spawn innovations, in order to allow each person to develop his or her project and to best position it within the landscape under reconstruction. This process of public revealing contributes to legitimising these values, because even though they are progressing in favour of ecologisation, their legitimacy to support a large and coherent societal transformation movement remains uncertain (Borrás and Edler 2014). This is all the truer considering that some stakeholders doubt the very possibility of achieving change, as van Mierlo et al. (2017: 11) have emphasised " $a$ large divide exists between those who think that we should and can change our ways of producing and consuming food, and those who doubt the potential of alternative 
ways of farming to halt climate change and radically reduce environmental risks". Additionally, the question of the legitimacy of the technological innovations chosen is coming up increasingly frequently, including in research communities (Schlaile et al. 2017). It therefore remains crucial to develop these arenas of discussion (i.e. transition arenas, Boulanger 2008) between different stakeholders to hone the new goals that a society, sector, or territory wishes to achieve. Constructing a common vision of the desired future, even if nobody can exactly foresee the system that the transition process will bring about, is an essential stage in the process. Moreover, even though starting these meetings may be difficult, their perpetuation over time will allow for the development of new and shared reflections that will address the legitimacy of the choices made. In this sense, the Etats Généraux de l'Alimentation launched by the French government in 2017 at national and regional level, as well as the participatory workshops of the TATA-BOX project across a delimited territory, constitute experiments in discussion arenas to facilitate the convergence of different visions. These "transition arenas" must receive the support of public resources (Smith et al. 2005), for converging actions will stem from converging visions.

It is also necessary to define different modes of governance based on the intentionality attributed to this transition (Smith et al. 2005). Given that it is embedded within a political intention, the governance mode can be more directive and coordinated than in the context of a transition resulting from more contingent processes. Therefore, the state must increase pressure on the dominant regime to promote the change via regulatory measures, providing new resources, or the recognition of distinctive markings. It is also necessary to increase the allocation of resources to networks of stakeholders that constitute niches, in order to allow them to evaluate their devices and continue to develop. It also falls upon niches to exert pressure on the institutional framework, to drive it to in turn exert pressure on the dominant regime so that the latter is more inclined to adopt the practices resulting from niches (cf. the "stretch and transform" process in Smith and Raven 2012). The ability of niches to interact with the institutional framework, in particular through the acknowledgement of elected officials, is recognised as an essential condition in the regime transformation process (Beers and Van Mierlo 2017).

Given that the spreading of innovation niches conveying radical innovations to the sociotechnical regime is essential to the transition process, it remains necessary to better understand the complexity of the relations that are woven between stakeholders in the dominant regime and niches. Actor network approaches may be able to help with this.

This point also suggests that the adaptive capacities of the dominant regime are just as important as those of niches or of the farm positioned as an essential link in experimenting with alternatives. Research is therefore needed to better understand the sources of this capacity of regime stakeholders to adapt to and integrate new knowledge and practices built around a new conception of cropping systems or of commercialisation and retailing. 
Even though this chapter has focused on a conception of the agricultural system in relation to the food system, based on a sociotechnical transition approach, it nonetheless remains interesting also to focus on the socio-ecological systems literature. Transition governance must also be defined in a way that includes the management of the natural resources affected by this agroecological transition.

Acknowledgment This research was supported by the TATA-BOX project funded by the French Research Agency (ANR-13-AGRO-0006; 2014-2018) and by the PSDR 4 Programme (Project ATA-RI. 2016-2020) funded by INRA and the Region Occitanie.

\section{References}

Anses (2016) Actualisation des repères du PNNS: révision des repères de consommations alimentaires, Avis de l'Anses, Rapport d'expertise collective, December

Arthur WB (1989) Competing technologies, increasing returns, and lock-in by historical events. Econ J 99:116-131. https://doi.org/10.2307/2234208

Barbier M, Elzen B (eds) (2012) System innovations, knowledge regimes, and design practices towards transitions for sustainable agriculture, INRA Editi. Paris, France

Barbier C, Cerf M, Lusson JM (2015) Cours de vie d'agriculteurs allant vers l'économie en intrants: les plaisirs associés aux changements de pratiques. Activites. https://doi.org/10.4000/ activites. 1081

Beers PJ, Van Mierlo B (2017) Reflexivity, reflection and learning in the context of system innovation: prying loose entangled concepts. In: Elzen B, Augustyn AM, Barbier M, van Mierlo B (eds) AgroEcological transitions. Wageningen University \& Research, Wageningen, pp 243-256

Bellon-Maurel V, Huyghe C (2016) L'innovation technologique dans l'agriculture. Géoéconomie 80:159-180. https://doi.org/10.3917/geoec.080.0159

Bize N (2017) Trajectoires de conversion à l'Agriculture Biologique en élevage bovin lait: Analyse rétrospective et actuelle. Rapport de stage

Bonaudo T, Bendahan AB, Sabatier R et al (2014) Agroecological principles for the redesign of integrated crop-livestock systems. Eur J Agron 57:43-51. https://doi.org/10.1016/j. eja.2013.09.010

Borrás S, Edler J (eds) (2014) The governance of socio-technical systems: explaining change. Edward Elgar Publishing, Cheltenham

Boulanger PM (2008) Une gouvernance du changement sociétal: le transition management. La Rev Nouv 11:61-73

Bouttes M, Darnhofer I, Martin G (2018) Converting to organic farming as a way to enhance adaptive capacity. Accepted with minor revision

Brauch HG, Spring ÚO, Grin J, Scheffran J (eds) (2016) Handbook on sustainability transition and sustainable peace. Springer International Publishing, Cham

Bremmer B, Bos B (2017) Creating niches by applying reflexive interactive design. In: Elzen B, Augustyn AM, Barbier M, van Mierlo B (eds) AgroEcological transitions. Wageningen University \& Research, Wageningen

Brown G, Kraftl P, Pickerill J, Upton C (2012) Holding the future together: towards a theorisation of the spaces and times of transition. Environ Plan A 44:1607-1623. https://doi.org/10.1068/ a44608

Brown JP, Goetz SJ, Ahearn MC, Liang C (2013) Linkages between community-focused agriculture, farm sales, and regional growth. Econ Dev Q 28:5-16. https://doi. org/10.1177/0891242413506610 
Bui S, Cardona A, Lamine C, Cerf M (2016) Sustainability transitions: insights on processes of niche-regime interaction and regime reconfiguration in agri-food systems. J Rural Stud 48:92103. https://doi.org/10.1016/j.jrurstud.2016.10.003

Buman T (2013) Opportunity now: integrate conservation with precision agriculture. J Soil Water Conserv 68:96A-98A

Campbell H (2009) The challenge of corporate environmentalism: social legitimacy, ecological feedbacks and the 'food from some where' regime? Agric Hum Values 26(4):309-319

Caron P, Biénabe E, Hainzelin E (2014) Making transition towards ecological intensification of agriculture a reality: the gaps in and the role of scientific knowledge. Curr Opin Environ Sustain 8:44-52. https://doi.org/10.1016/j.cosust.2014.08.004

Cayre P, Michaud A, Theau JP, Rigolot C (2018) The coexistence of multiple worldviews in livestock farming drives agroecological transition. A case study in French protected designation of origin (PDO) cheese mountain areas. Sustainability 10:1097. https://doi.org/10.3390/ su10041097

Chang R, Zuo J, Zhao Z et al (2017) Approaches for transitions towards sustainable development: status quo and challenges. Sustain Dev 25:359-371. https://doi.org/10.1002/sd.1661

Chantre E, Cardona A (2014) Trajectories of French field crop farmers moving toward sustainable farming practices: change, learning, and links with the advisory services. Agroecol Sustain Food Syst 38:573-602. https://doi.org/10.1080/21683565.2013.876483

Chantre E, Cerf M, Le Bail M (2015) Transitional pathways towards input reduction on French field crop farms. Int J Agric Sustain 13:69-86. https://doi.org/10.1080/14735903.2014.945316

Charrier F, Hannachi M, Barbier M, Casabianca F (2017) Décider ensemble pour que l'impossible devienne possible. La co-construction d'un dispositif de gestion d'une maladie animale en Corse. In: 7th OPDE conference "des Outils pour Décider ensemble"; Montpellier, 26-27 of October 2017, 2017. p 21

Cholez C, Magrini MB, Galliano D (2017) Field crop production contracts. Incentives and coordination under technical uncertainty, in French cooperatives. Économie Rural 360(4):65-83. https://doi.org/10.4000/economierurale.5260

Coquil X, Béguin P, Dedieu B (2014) Transition to self-sufficient mixed crop-dairy farming systems. Renew Agric Food Syst 29:195-205. https://doi.org/10.1017/S1742170513000458

Coquil X, Dedieu B, Béguin P (2017) Professional transitions towards sustainable farming systems: the development of farmers' professional worlds. Work 57:325-337. https://doi.org/10.3233/ WOR-172565

Cowan R, Gunby P (1996) Sprayed to death: path dependence, lock-in and pest control strategies. Econ J 106:521-542. https://doi.org/10.2307/2235561

Cristofari H, Girard N, Magda D (2018) How agroecological farmers develop their own practices: a framework to describe their learning processes. Agroecol Sustain Food Syst 42:777-795. https://doi.org/10.1080/21683565.2018.1448032

D’Alisa G, Demaria F, Kallis G (eds) (2014) Degrowth: a vocabulary for a new era. Routledge, New York/London

Darnhofer I, Bellon S, Dedieu B, Milestad R (2010) Adaptiveness to enhance the sustainability of farming systems. A review. Agron Sustain Dev 30:545-555. https://doi.org/10.1051/ agro/2009053

de Boer J, Aiking H (2018) Prospects for pro-environmental protein consumption in Europe: cultural, culinary, economic and psychological factors. Appetite 121:29-40. https://doi. org/10.1016/j.appet.2017.10.042

Dessein J, Nevens F (2007) "I'm sad to be glad". An analysis of farmers' pride in Flanders. Sociol Ruralis 47:273-292. https://doi.org/10.1111/j.1467-9523.2007.00437.x

Diaz M, Darnhofer I, Darrot C, Beuret JE (2013) Green tides in Brittany: what can we learn about niche-regime interactions? Environ Innov Soc Trans 8:62-75. https://doi.org/10.1016/j. eist.2013.04.002

Duru M, Therond O, Fares M (2015a) Designing agroecological transitions; a review. Agron Sustain Dev 35:1237-1257. https://doi.org/10.1007/s13593-015-0318-x 
Duru M, Therond O, Martin G et al (2015b) How to implement biodiversity-based agriculture to enhance ecosystem services: a review. Agron Sustain Dev 35:1259-1281. https://doi. org/10.1007/s13593-015-0306-1

Elzen B, Geels FW, Green K (2004) System innovation and the transition to sustainability: theory, evidence and policy. Edward Elgar Publishing, Cheltenham

Elzen B, Leeuwis C, van Mierlo BC (2008) Anchorage of innovations: assessing Dutch efforts to use the greenhouse effect as an energy source. Wageningen University and Research, Wageningen

Elzen B, Geels FW, Leeuwis C, van Mierlo B (2011) Normative contestation in transitions 'in the making': animal welfare concerns and system innovation in pig husbandry. Res Policy 40:263-275. https://doi.org/10.1016/j.respol.2010.09.018

Elzen B, Augustyn AM, Barbier M, van Mierlo B (eds) (2017) AgroEcological transitions. Wageningen University \& Research, Wageningen

FAO (2012) Sustainable diets and biodiversity. Corporate authors: FAO, Rome and biodiversity international, Rome, Italy

Fenzi M, Bonneuil C (2016) From "genetic resources" to "ecosystems services": a century of science and global policies for crop diversity conservation. Cult Agric Food Environ 38:72-83. https://doi.org/10.1111/cuag.12072

Foxon T (2011) A coevolutionary framework for analysing a transition to a sustainable low carbon economy. Ecol Econ 70:2258-2267

Francis C, Lieblein G, Gliessman S et al (2003) Agroecology: the ecology of food systems. J Sustain Agric 22:99-118. https://doi.org/10.1300/J064v22n03_10

Geels FW (2004) From sectoral systems of innovation to socio-technical systems. Res Policy 33:897-920. https://doi.org/10.1016/j.respol.2004.01.015

Geels FW (2011) The multi-level perspective on sustainability transitions: responses to seven criticisms. Environ Innov Soc Trans 1:24-40. https://doi.org/10.1016/j.eist.2011.02.002

Geels FW (2012) A socio-technical analysis of low-carbon transitions: introducing the multilevel perspective into transport studies. J Transp Geogr 24:471-482. https://doi.org/10.1016/j. jtrangeo.2012.01.021

Gliessman SR (2015) Agroecology: the ecology of sustainable food systems, third edit. Taylor \& Francis, Boca Raton

Gomant F (2017) Images des agriculteurs auprès du grand public. In: Demeter 2017, 23rd edn, pp 6-17

Hartmann C, Siegrist M (2017) Consumer perception and behaviour regarding sustainable protein consumption: a systematic review. Trends Food Sci Technol 61:11-25. https://doi. org/10.1016/j.tifs.2016.12.006

Hinrichs CC (2014) Transitions to sustainability: a change in thinking about food systems change? Agric Human Values 31:143-155. https://doi.org/10.1007/s10460-014-9479-5

Hoibian S (2010) Enquête sur les attitudes et comportements des Français en matière d'environnement (2010 edition), Study conducted by the ADEME, Collection des rapports du CRÉDOC, ${ }^{\circ} 270$, October 2010,

Horlings LG, Marsden TK (2011) Towards the real green revolution? Exploring the conceptual dimension of a new ecological modernisation of agriculture that couls "feed the world". Glob Environ Chang 21:441-452. https://doi.org/10.1016/j.gloenvcha.2011.01.004

Ingram J (2008) Agronomist-farmer knowledge encounters: an analysis of knowledge exchange in the context of best management practices in England. Agric Human Values 25:405-418. https://doi.org/10.1007/s10460-008-9134-0

Ingram J (2015) Framing niche-regime linkage as adaptation: an analysis of learning and innovation networks for sustainable agriculture across Europe. J Rural Stud 40:59-75. https://doi. org/10.1016/j.jrurstud.2015.06.003

Ingram J (2018) Agricultural transition: niche and regime knowledge systems' boundary dynamics. Environ Innov Soc Trans 26:117-135. https://doi.org/10.1016/j.eist.2017.05.001

Klerkx L, van Mierlo B, Leeuwis C (2012) Evolution of systems approaches to agricultural innovation: concepts, analysis and interventions. In: Darnhofer I, Gibbon D, Dedieu B (eds) Farming systems research into the 21st century: the new dynamic. Springer, Dordrecht, pp 359-385 
Kremen C, Iles A, Bacon C (2012) Diversified farming systems: an agroecological, systemsbased alternative to modern industrial agriculture. Ecol Soc 17:44. https://doi.org/10.5751/ ES-05103-170444

Lachman DA (2013) A survey and review of approaches to study transitions. Energy Policy 58:269-276. https://doi.org/10.1016/j.enpol.2013.03.013

Lamine C (2011) Anticiper ou temporiser. Injonctions environnementales et recompositions des identités professionnelles en céréaliculture. Sociol Trav 53:75-92

Lascialfari M, Magrini MB, Triboulet P (Forthcoming 2019) The drivers of product innovations in pulsed-based foods: insights from cases studies in France, Italy and USA, Revue Innovations

Levidow L, Birch K, Papaioannou T (2012) Divergent paradigms of European agro-food innovation: the knowledge-based bio-economy (KBBE) as an R\&D agenda. Sci Technol Hum Values 38:94-125. https://doi.org/10.1177/0162243912438143

Lhoste V (2017) La diffusion du concept d'agroécologie au sein des standards de produits alimentaires en France. Rapport ODR

Loorbach D, Rotmans J (2010) The practice of transition management: examples and lessons from four distinct cases. Futures 42:237-246. https://doi.org/10.1016/j.futures.2009.11.009

Lubello P, Falque A, Temri L (eds) (2017) Systèmes agroalimentaires en transition, éditions QUAE

Lusson J, Coquil X, Frappat B, Falaise D (2014) 40 itinéraires vers des systèmes herbagers: comprendre les transitions pour mieux les accompagner. Fourrages 219:213-220

Magne MA, Thénard V, Mihout S (2016) Initial insights on the performances and management of dairy cattle herds combining two breeds with contrasting features. Animal 10:892-901. https:// doi.org/10.1017/S1751731115002840

Magne MA, Ollion E, Cournut S, et al (2017) Some key research questions about the interest of animal diversity for the agroecological transition of livestock farming systems. In: First agroecology Europe forum fostering synergies between movement, science and practice, 25-27 October 2017, Lyon, France

Magrini MB, Duru M (2015) Diffusion d'une niche d'innovation dans les systèmes sociotechniques laitiers : coordination, standards et co-évolution. Une analyse de la démarche BleuBlanc-Coeur en France. Rev Innov 48:187-210

Magrini MB, Anton M, Cholez C et al (2016) Why are grain-legumes rarely present in cropping systems despite their environmental and nutritional benefits? Analyzing lock-in in the French agrifood system. Ecol Econ 126:152-162. https://doi.org/10.1016/j.ecolecon.2016.03.024

Magrini MB, Anton M, Cholez C et al (2017) Transition vers des systèmes agricole et agroalimentaire durables: quelle place et qualification pour les légumineuses à graines? Rev Française Socio-Économie 18:53-75. https://doi.org/10.3917/rfse.018.0053

Magrini MB, Befort N, Nieddu M (2018) Economic dynamics of technological trajectories and pathways of crop diversification in bio-economy. In: Lemaire G, Carvalho P, Kronberg S, Recous S (eds) Agro-ecosystem diversity: reconciling contemporary agriculture and environment quality. Elsevier Academic Press, Amsterdam, p 478

Marshall NA, Stokes CJ, Webb NP et al (2014) Social vulnerability to climate change in primary producers: a typology approach. Agric Ecosyst Environ 186:86-93. https://doi.org/10.1016/j. agee.2014.01.004

Martin G, Magne MA (2015) Agricultural diversity to increase adaptive capacity and reduce vulnerability of livestock systems against weather variability - a farm-scale simulation study. Agric Ecosyst Environ 199:301-311. https://doi.org/10.1016/j.agee.2014.10.006

Martin G, Felten B, Duru M (2011) Forage rummy: a game to support the participatory design of adapted livestock systems. Environ Model Softw 26:1442-1453. https://doi.org/10.1016/j. envsoft.2011.08.013

Mazé A (2017) Standard-setting activities and new institutional economics. J Inst Econ 13:599 621. https://doi.org/10.1017/S174413741600045X

Meybeck A, Gitz V (2017) L'expérience du programme FAO/PNUE pour des systèmes alimentaires durables. Rev AES 7:69-73 
Meynard JM (2017) L'agroécologie, un nouveau rapport aux savoirs et à l'innovation. OCL 24:D303. https://doi.org/10.1051/ocl/2017021

Meynard J, Messéan A, Charlier A, et al (2015) La diversification des cultures: lever les obstacles agronomiques et économiques, Quae. Versailles

Meynard JM, Jeuffroy MH, Le Bail M et al (2017) Designing coupled innovations for the sustainability transition of agrifood systems. Agric Syst 157:330-339. https://doi.org/10.1016/j. agsy.2016.08.002

Moser SC, Ekstrom JA (2010) A framework to diagnose barriers to climate change adaptation. Proc Natl Acad Sci 107:22026-22031. https://doi.org/10.1073/pnas.1007887107

Nazari S, Pezeshki G, Sedighi H, Azadi H (2015) Vulnerability of wheat farmers: toward a conceptual framework. Ecol Indic 52:517-532. https://doi.org/10.1016/j.ecolind.2015.01.006

Nelson DR, Adger WN, Brown K (2007) Adaptation to environmental change: contributions of a resilience framework. Annu Rev Environ Resour 32:395-419. https://doi.org/10.1146/annurev. energy.32.051807.090348

Nozières MO, Baritaux V, Cournut S, et al (2014) Describing the evolutions, in a territory, of the interactions between livestock farming systems and downstream operators. Proposal for a methodological framework, based on the comparison of 4 territories and 2 types of production: milk and meat. In: 11th European IFSA Symposium "Farming systems facing global challenges: Capacities and strategies", 01 to 04 of April 2014, Berlin. p 12

OECD (2010) Eco-innovation in industry: enabling green growth. OECD Publishing, Paris

Ollion E, Brives H, Cloet E, Magne MA (2018) Suitable cows for grass-based systems: what stakeholders do in France? In: 28th EGF General Meeting on "Sustainable Meat and Milk Production from Grasslands", Ireland, 17th-21st June 2018

Olsson P, Folke C, Berkes F (2004) Adaptive comanagement for building resilience in socialâ€"ecological systems. Environ Manag 34:75-90

Padel S (2001) Conversion to organic farming: a typical example of the diffusion of an innovation? Sociol Ruralis 41:40-61. https://doi.org/10.1111/1467-9523.00169

Pérole G (2017) A Mouans-Sartoux, une restauration collective issue intégralement de l'agriculture biologique depuis 2012. Rev AE\&S 7:119-121

Picard F, Tanguy C (2016) Innovations and techno-ecological transition. Wiley, Hoboken, pp 59-86

Plumecocq G, Debril T, Duru M et al (2018) The plurality of values in sustainable agriculture models: diverse lock-in and coevolution patterns. Ecol Soc 23. https://doi.org/10.5751/ ES-09881-230121

Raven R, Kern F, Verhees B, Smith A (2016) Niche construction and empowerment through sociopolitical work. A meta-analysis of six low-carbon technology cases. Environ Innov Soc Trans 18:164-180. https://doi.org/10.1016/j.eist.2015.02.002

Reed MS, Allen K, Attlee A et al (2017) A place-based approach to payments for ecosystem services. Glob Environ Chang 43:92-106. https://doi.org/10.1016/j.gloenvcha.2016.12.009

Schlaile M, Urmetzer S, Blok V et al (2017) Innovation systems for transformations towards sustainability? Taking the normative dimension seriously. Sustainability 9:2253. https://doi. org/10.3390/su9122253

Schmitt E, Galli F, Menozzi D et al (2017) Comparing the sustainability of local and global food products in Europe. J Clean Prod 165:346-359. https://doi.org/10.1016/j.jclepro.2017.07.039

Simonneaux L, Simonneaux J, Cancian N (2016) QSV Agro-environnementales et changements de société: Transition éducative pour une transition de société via la transition agroécologique

Singh JS, Pandey VC, Singh DP (2011) Efficient soil microorganisms: a new dimension for sustainable agriculture and environmental development. Agric Ecosyst Environ 140:339-353. https://doi.org/10.1016/j.agee.2011.01.017

Smith A, Raven R (2012) What is protective space? Reconsidering niches in transitions to sustainability. Res Policy 41:1025-1036. https://doi.org/10.1016/j.respol.2011.12.012

Smith A, Stirling A, Berkhout F (2005) The governance of sustainable socio-technical transitions. Res Policy 34:1491-1510. https://doi.org/10.1016/j.respol.2005.07.005

Soufflet JF (1990) Compétitivité et stratégies agro-industrielles dans la filière viande bovine européenne en constitution. Économie Rural 197:42-48. https://doi.org/10.3406/ecoru.1990.4060 
Soulignac V, Pinet F, Lambert E et al (2017) GECO, the French web-based application for knowledge management in agroecology. Elsevier Comput Electron Agric 29. https://doi. org/10.1016/j.compag.2017.10.028

Sovacool BK (2016) How long will it take? Conceptualizing the temporal dynamics of energy transitions. Energy Res Soc Sci 13:202-215. https://doi.org/10.1016/j.erss.2015.12.020

Therond O, Duru M, Roger-Estrade J, Richard G (2017) A new analytical framework of farming system and agriculture model diversities. A review. Agron Sustain Dev 37:21. https://doi. org/10.1007/s13593-017-0429-7

Triboulet P, Cuq B, Lullien-Pellerin V et al (2018) Les français et le blé dur. Ind des céréales 206:8-13

van Mierlo B, Augustyn A, Elzen B, Barbier M (2017) AgroEcological transitions: changes and breakthroughs in the making. In: Elzen B, Augustyn A, Barbier M, van Mierlo B (eds) Agroecological transitions: changes and breakthroughs in the making. Wageningen University \& Research, Wageningen, pp 9-16

Vankeerberghen A, Stassart PM (2016) The transition to conservation agriculture: an insularization process towards sustainability. Int J Agric Sustain 14:392-407. https://doi.org/10.1080/14735 903.2016.1141561

Vanloqueren G, Baret PV (2009) How agricultural research systems shape a technological regime that develops genetic engineering but locks out agroecological innovations. Res Policy 38:971983. https://doi.org/10.1016/j.respol.2009.02.008

Vogl CR, Kummer S, Leitgeb F et al (2015) Keeping the actors in the organic system learning: the role of organic farmers' experiments. Sustain Agric Res 4:140-148. https://doi.org/10.5539/ sar.v4n3p140

Warner K (2007) Agroecology in action: extending alternative agriculture through social networks. MIT Press, Cambridge

Weiner J (2017) Applying plant ecological knowledge to increase agricultural sustainability. J Ecol 105:865-870. https://doi.org/10.1111/1365-2745.12792

Open Access This chapter is licensed under the terms of the Creative Commons Attribution 4.0 International License (http://creativecommons.org/licenses/by/4.0/), which permits use, sharing, adaptation, distribution and reproduction in any medium or format, as long as you give appropriate credit to the original author(s) and the source, provide a link to the Creative Commons licence and indicate if changes were made.

The images or other third party material in this chapter are included in the chapter's Creative Commons licence, unless indicated otherwise in a credit line to the material. If material is not included in the chapter's Creative Commons licence and your intended use is not permitted by statutory regulation or exceeds the permitted use, you will need to obtain permission directly from the copyright holder.

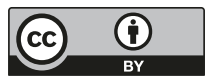

